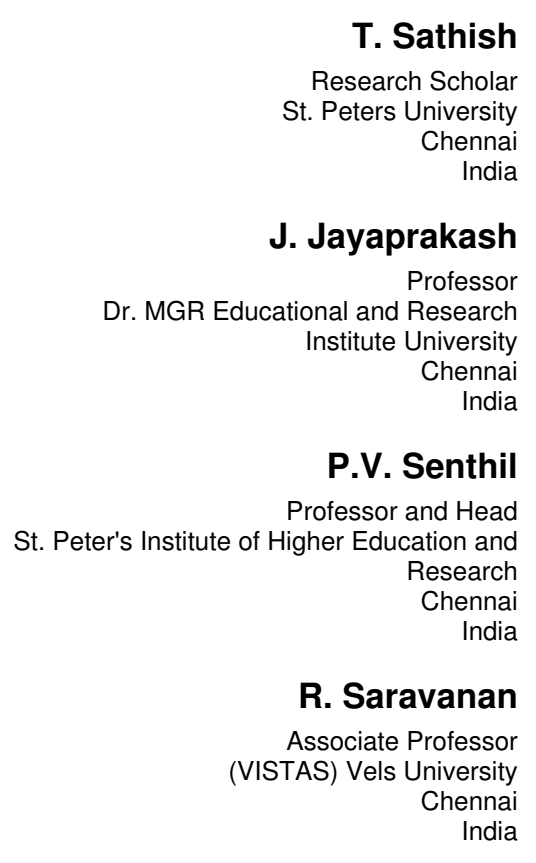

T. Sathish

Research Scholar

Chennai

dia

tessor

search

Chennai

India

P.V. Senthil

Professor and Head Research

ennai dia

R. Saravanan VISTAS) Vels University Chennai

\section{Multi Period Disassembly-to-Order of End of Life Product based on scheduling to maximize the Profit in Reverse Logistic Operation}

\begin{abstract}
In recent era, the creation of electronic contraptions is expanding step by step, which leads to tremendous electronic waste. This is the condition drives as a result of the current individuals expecting new innovation in a brief time. This circumstance makes the manufacturers in a circumstance to create the new item in a brief time, so the current items need to either be disposed or dismantled. In this circumstance the manufactures wanted to re-manufacture the end-of-life (E-O-L) items to meet the component necessity in the new items production. In this sense in our previous work we exhibited a methodology to choose the optimal number of take back product, so that the aggregate expense needed for the reverse logistic $(R L)$ can be lessened. In this paper, we exhibited a novel methodology for the $R L$ operation of E-O-L items, in view of an optimal scheduling algorithm. In the previous work we have located the optimal number of take back E-O-L products for the disassembly-to-order (D-T-O), and this paper displayed the procedure to legitimately schedule the machines to disassemble the products, so that the aggregate time as well as the total cost needed for the RL operation can be diminished. In the proposed structure artificial bee colony $(A B C)$ algorithm is utilized. The proposed framework drives the preferred performance over the existing scheduling algorithms.
\end{abstract}

Keywords reverse logistic, end-of-life product, disassembly-to-order, meta-heuristic optimization, artificial bee colony algorithm, disassembly scheduling.

\section{INTRODUCTION}

It is disheartening that our modern hi-tech era of chips and bytes is plagued by two of the most outstanding challenges staring at its face such as the exhaustion of the natural energy and resources and the ecocontamination on account of the disposal of waste and obsolete products [1, 2]. An innovative reverse logistics (RL) function goes a long way in empowering entities with the skill of better utilization of eco-energy and resources and accomplishment of a sober trade-off between financial system and eco-spectrum [3]. Online purchases, mail order and after-sales have contributed their mite in the rocking rate of returns in the organizations, which have miserably failed to focus further on zooming rewards. In view of the variations in legislative measures, intended both for eco-friendliness and service interests, a lion's share of organization is seen resorting to the course of reverse flows which constitute going in the backward direction from clients to recovery hubs located within their logistics network [4]. Reprocessing of consumer goods does remain no

Received: October 2015, Accepted: September 2016 Correspondence to: Professor P.V. Senthil,

St. Peter's Institute of Higher Education and Research, Chennai, India

E-mail: tsathishphd@gmail.com

doi:10.5937/fmet1701172S

(C) Faculty of Mechanical Engineering, Belgrade. All rights reserved longer an innovation. Waste paper reuse, soft drink bottles collection, metal scrap brokers have significantly become common place in every- day life. The reprocess of consumed materials brings with it various features such as collection, organization and processing, and the triumph is factored by the skills attained by means of apt synchronization and assimilation. Reverse logistics, in turn, is driven by various factors such as competition and marketing objectives, direct financial causes together with the growing anxieties over the ecosystem. It is a significant fact that it possesses eco dimensions along with dimensions in terms of value retrieval [5-9].

Outdated products are also often labeled as end-oflife (EOL) products. There is a feast of techniques to administer these products, such as reprocess, reuse or disposal, to name a few. Disposal, in turn, causes further decreases in the number of landfills portending a grave threat to ecosystem unless it is handled judiciously. All concerned inclusive of the Government, the producers and end-users are effectively enlightened of the inherent threats, paving the way for the framing of various eco-friendly rules and regulations. It is a welcome sign that a large slice of the EOL products maintain a superb functioning trend, it is highly desirable to exploit them by either reprocess or reuse, which eventually leads to the considerable economy in component acquirement and product clearance outlays [10]. 
The tempo of product returned by the consumers is alarmingly high for magazines, photocopiers, computers, cameras, cellular phones, books, apparels, and automobile, electronic, aircraft components, chemical and medical items. The aggrieved clients tend to make a clarion call for substitution of products deemed deficient in quality. The range of product returns goes sky high involving certain industries to the tune of more than half of the sale values. Since the last decade life-long return regulations have been doing the rounds in the developed countries, forcing the business magnates to efficiently administer the whole life of the product and in this regard clients play a prominent part by placing the ball in the court of the businesses to assume accountability of the dumping of their products. [11]. Returned products are gathered, scrutinized and classified by employees to in line with their skills. Moreover, the employee regulates, when the return is accepted, and further measures are taken. Anyhow the main anxiety is regarding the fact whether the recuperation of products is more cost-effective than the dumping of the products. A major chunk of the supply chain management focuses on the forward motion and renovation of the materials from the suppliers downstream to the end clients and the sway the change wields on the bullwhip effect. Nevertheless, the reverse flow of products from the clients on upstream business has not evinced any significant enthusiasm [12].

Disassembly is the initial procedure to regain components and materials from EOL products for reconsumption and reprocess. As the take-back products return to the company in varied of conditions, it is hard to have a prior knowledge of exactly how many products are required for disassembly to meet the demand for components and materials. No wonder, this ambiguity ends up further complicating the disassembly procedure $[13,14]$. One of the significant methods to administer the resultant menace is to resort to the employment of heuristic process to transform the stochastic brand into a deterministic mode and then set out to solve the deterministic menace [15]. In consequence, the fundamental aim here is to optimize the number of take-back products to be disassembled so as to enhance the profit of selling components and materials, without in any way causing damage to the eco-system. In the proposed system we planned to reduce the time taken for RL process by using an optimal scheduling algorithm.

The rest of the paper is organized as follows: some of the recent researches related to the reverse logistic of E-O-L products is given in section 2. The section 3 clearly describes the proposed scheduling algorithm. In section 4 the results obtained by the Matlab implementation and performance analysis is given. In the subsequent sections conclusion and reference are given.

\section{RELATED WORK}

Some of the recent research work related to the E-O-L reverse logistic is listed below:

Most past articles on disassembly scheduling are incapacitated ones, i.e., the asset limit imperatives are not considered. Gupta and Taleb [16] consider the essential case, i.e., single item sort without parts shared characteristic, and recommend a straightforward calculation without unequivocal target capacity, and Lee and Xirouchakis [17] propose a heuristic calculation for the goal of minimizing the expenses related with dismantling procedure. For the expanded models with parts shared characteristic and/or various item sorts, see Kim et al. [18], Taleb and Gupta [19], and Taleb et al. [20]. As of late, Lee et al. [21] present whole number programming models for all the uncapacitated cases together with their exhibitions. Dissimilar to these, Lee et al. [22] consider the asset limit requirements unequivocally and propose a whole number programming model with different expense components happened in dismantling procedures. Despite the fact that the model can give ideal arrangements, its application is constrained just to the little measured issues. Truth be told, the computational results demonstrate that it is not sufficient for pragmatic estimated issues because of its unreasonable processing times.

Luu Quoc Dat et al. [23] have subjectively conceived a scientific programming model that abbreviates the general handling costs of various classes of waste electrical and electronic items (WEEPs). Chunguang Bai et al. [24] have charmingly conveyed to spotlight an imaginative converse logistics adaptability structure, which is divided into practical operational and vital adaptabilities. Mahdi Mahmoudzadeh et al. [25] have radiantly propelled an imaginative technique to depict suitable assumptions in appreciation of distinct circumstance of end-of-life (ELVs) organization in Iran to adjust the issue as an outsider opposite logistics system. Sónia R. Cardoso et al. [26] have efficiently offered an imaginative blended whole number straight programming (MILP) strategy which is expected for the configuration and arranging of supply chains with opposite streams notwithstanding simultaneous assessment of generation, dissemination and converse logistics capacities. Harold Krikke et al. [27] have charmingly offered comprehensive bright information on the assessment of current return works out. They have planned the test recommendations on the drivers, volumes and estimation of different returns for the duration of the life cycle displaying the inadequacy in present day return works on bringing about quality decay instead of the advanced worth development and assess and complexity return hones in different districts and commercial enterprises. They have likewise outfitted tributes for transforming quality decay into worth expansion. Despite the fact that the fancied advancement is not came to, it is trusted that the capability of profits administration is situated for determination in the days to come.

\section{PROPOSED ABC BASED SCHEDULING APP_ ROACH FOR MULTI PERIOD DTO OF EOL PRODUCTS}

In order to obtain the maximum yield from the reverse logistic of E-O-L products the D-T-O is a crucial procedure. In D-T-O process the sought components or 
materials are expelled efficiently from the take back E$\mathrm{O}-\mathrm{L}$ products. However the D-T-O is one of the hardest procedure while performing the E-O-L RL. In the previous work we have proposed an Adaptive Genetic Algorithm (AGA) based method for selecting the appropriate number of E-O-L to take back for the D-T$\mathrm{O}$ [28]. The previous work effectively reduced the operational cost of RL process of E-O-L products by selecting the proper combination of products. In this paper we proposed a novel methodology to appropriately schedule the selected item for D-T-O process, so that the time required for the dismantling get lessened in the interim legitimate scheduling can also reduce the total cost required for the RL operation. The proposed framework for scheduling is based on the artificial bee colony algorithm (ABC). The construction modelling for the proposed framework is given in fig 1 .

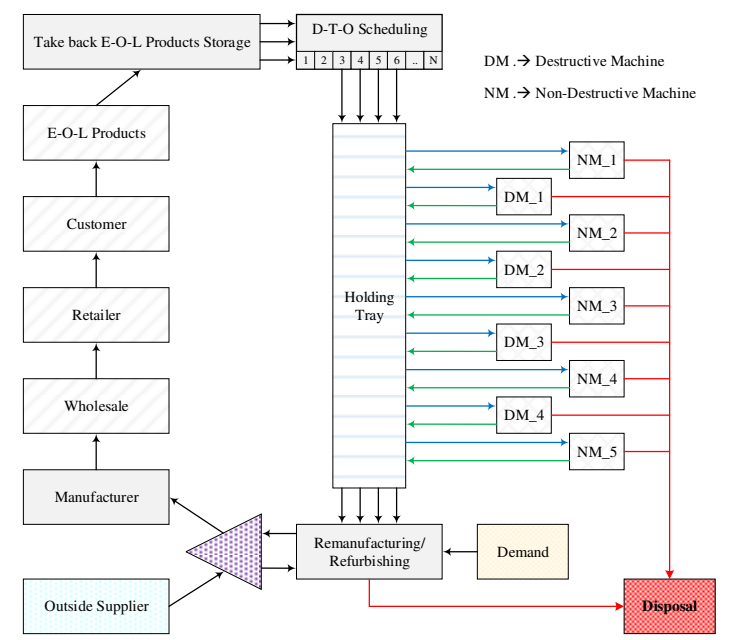

Figure 1: Construction modelling of proposed framework

Dismantling can be selective, complete, destructive, non-destructive, and so forth. In this paper, we are focusing on the destructive and non-destructive disassembly of E-O-L items. The fig. 1 demonstrates the proposed D-T-O structure construction modelling, in which the procedure stream from the collection point to the dispose is given in subtle element. The obtained E$\mathrm{O}-\mathrm{L}$ items from the outside plant are kept in the collection point, in that point these items are sent for dismantling. The dismantled or disassembled products are sorted into two kind in particular Destructive and Non-destructive. The components from the nondestructive disassembly are directly sent for the reuse or refurbishing purpose. The materials recovered from the destructive dismantling are sent for the recycle or remanufacturing. Some of the damaged products also recovered from the non-destructive dismantling and which are sent for the recycle. The recycling can be performed in two ways i.e. in-plant and out-plant recycle. In-plant recycle the re-manufacturing is occur in the home organization or company. Then again in the out-plant recycle the items are sent to the other organization or company for re-manufacturing. The abundance of component obtained from the nondestructive disassembly is disposed i.e. after fulfilled the reuse demand. Correspondingly the items excluded from destructive disassembly are sent for disposed. What's more, if the disassembled parts not satisfied the demand, those need to purchase from an outside supplier. The optimal number of product to collect form the entire E-O-L product is done in past paper [28] by utilizing AGA. In this paper the scheduling based system for the best possible disassembly, to diminish the disassembly time and maximize the benefit.

\subsection{Objective Formation}

The D-T-O is the critical process in E-O-L product reverse logistic, in which disassembly of the E-O-L product is performed from multiple points of view. A proper disassembly can give greatest benefit. The aggregate expense for spending the reverse logistic can lessened by a proper D-T-O process. In this manner the principle goal of work is to minimize the expense and time to spend for the reverse logistic of E-O-L products. The forecast of definite yield of component from the E-O-L is troublesome, on the other hand we can foresee the most extreme likelihood of yield can acquire from the E-O-L reverse logistic. The fig 1 demonstrates the construction modelling of the D-T-O, the diverse products under distinctive condition are kept in the collection point. With respect to the forecast is precise the demand of part get fulfilled. Something else, to satisfy the demand the parts need to purchase from the outside suppliers. In the event that the genuine yield is lower than the expectation, components need to buy to take care of the demand. In another case the yield is higher than the expectation; the overabundance components have to dispose. In this way, if the forecast is far least or most extreme than it make misfortune for the E-O-L reverse logistic operation. Subsequently the forecast should near to the genuine yield.

Two main objectives consider in this paper, which are minimization of total disassembly time and minimization of total cost. The total time required for the disassembly of destructive component and the total time required for the disassembly of non-destructive component can identify by using the following equations (1) and (2) respectively.

$$
\begin{aligned}
T_{D i} & =\sum_{i}\left(\left(E P_{i}-N D Y_{i}\right) \times t_{D M_{-} j}\right) \\
T_{N i} & =\sum_{i}\left(\left(N D Y_{i}\right) \times t_{N M_{-} i}\right)
\end{aligned}
$$

where, ' $T_{D i}$ ' is time required for disassembling of $i^{\text {th }}$ destructive component ( $\mathrm{Sec}$ ); ' $T_{N i}$ ' is time required for disassembling of $i^{\text {th }}$ Non-destructive component ( $\mathrm{sec}$ ); ' $t_{D M_{j} j}$ ' is average time taken by machine $j$ for disassembling of a destructive component (sec); ' $t_{N M_{j} j}$ ' is average time taken by machine $j$ for disassembling of a non-destructive component (sec); ' $E_{P i}$ ' is total E-O-L products in unit; and ' $N D Y$ ' is Non-destructive disassembly yield in $\%$.

The main objectives of our model is to minimize the total cost and disassembly time, the function for the total disassembly time is given in the below equation (3) and total cost can be calculated by using eqn. $(* 1)$.

$$
T_{D T O}=\sum_{i}\left(E P_{i} \cdot\left(T_{D i}+T_{N i}\right)\right)
$$

Where, ' $T_{\text {DтO }}$ - total time required for D-T-O (sec)); and $T_{D i}, T_{N i}>0$. 


$$
T C=\sum_{i}\left(E P_{i} \cdot b c_{i}\right)+\sum_{j}\left(p c_{j} \cdot P C_{j}\right)+\sum_{j}\left(d c_{j} \cdot D C_{j}\right)
$$

where,

$$
\begin{aligned}
& P C_{j}=\max \left[R U D_{j}-\sum_{i}\left(E P_{i} \cdot N D Y_{j}\right) ; 0\right] \\
& D C_{j}=\max \left[\sum_{i}\left(E P_{i} \cdot N D Y_{j}\right)-R U D_{j} ; 0\right] \\
& E P_{i}, P C_{j}, D C_{j} \geq 0
\end{aligned}
$$

' $b c_{i}$ '- unit take-back cost for product i (Rs/unit) ' $p c_{j}$ '- unit procurement cost for component type $\mathrm{j}$ (Rs/unit)

' $d c_{j}$ ' - unit disposing cost for component type $\mathrm{j}$ (Rs/unit)

' $P C_{j}$ ' - Total no of Procured Components in unit;

' $D C_{j}$ '- Total no of Disposed Component in unit;

' $R U D_{j}$ ' - jth type Reuse component demand in unit;

' $E P_{i}{ }^{\prime}$ ' - i type total E-O-L products in unit;

' $N D Y_{j}$ ' - Non-destructive disassembly yield in \%

The eqn. (3) is the total time required for the D-T-O process in the E-O-L reverse logistic. Then the objective of this work is to minimize the total time and total cost required for the disassembly process. Minimizing of the total DTO time function becomes a complex task in general case, because it may contain multiple product and component. Hence optimization is preferred for solving the scheduling task. In this work, we are choosing the artificial bee colony (ABC) optimization for solving the scheduling problem. The detailed discussion on the conventional $\mathrm{ABC}$ is given in the below section.

\subsection{ABC based Disassembly scheduling}

The artificial bee colony (ABC) algorithm, consist of three types of artificial bees, which are employed, onlookers and scouts. The employed bees collect the food source form the global search. The employed bees offer data with the onlooker bees, which are holding up in the hive and watching the dances of the employed bees. The onlooker bees will then pick a food source with likelihood corresponding to the nature of that sustenance source. In this manner, great food sources pull in a bigger number of honey bees than the awful ones. Scout honey bees scan for new food sources arbitrarily in the region of the hive. At the point when a scout or onlooker bee discovers a food source, it gets to be employed. At the point when a food source has been completely misused, all the employed bees connected with it will relinquish the position, and may get to be scouts once more. Consequently, scout bees perform the occupation of 'investigation', while employed and onlooker bees perform the employment of misuse'. Which encourage the work of the scout bee stage more hearty. In the proposed algorithm, a food source relates to a conceivable solution for the optimization problem, and the nectar measure of a food source compares to the wellness of the related solution. In $\mathrm{ABC}$, the first a large portion of the colony comprise of employed bees and the other half are onlookers. The quantity of employed honey bees is equivalent to the quantity of food sources in light of the fact that it is expected that there is one and only employed bee for every food source. Hence, the quantity of onlooker bees is likewise equivalent to the quantity of solutions under thought. The ABC algorithm begins with a gathering of haphazardly created food sources. The principle methodology of $\mathrm{ABC}$ can be depicted as takes after.

Step 1: Initialization of food sources.

Step 2: Employed bee get starts to work on food source.

Step 3: Onlooker bees elects a food source according to the nectar information shared by the employed bees.

Step 4: Determination of Scout bees, which will search for food sources in a random manner.

Step 5: Termination criteria testing to terminate the process otherwise repeat the process from step 2 .

The detailed description for each step is given below.

Initialization phase: In this initial phase of $\mathrm{ABC}$ algorithm, the food sources are randomly generated.

$$
F_{i}=\left\{F_{i, 1}, F_{i, 2}, \ldots, F_{i, D}\right\}
$$

$F_{i}$ represent the $i^{\text {th }}$ food source, which is obtained by

$$
F_{i, d}=F_{d}^{\min }+r \times\left(F_{d}^{\max }-F_{d}^{\min }\right)
$$

where $r$ is a uniform random number in the range [0,1] and $F_{d}^{\min }$ and $F_{d}^{\max }$ are the lower and upper bounds for dimension $d$ respectively $d=1, \ldots, D$.

Employed bee phase: In this stage, each employed bee is connected with a solution. It applies a random alteration on the solution for new solution. This executes the capacity of neighbourhood search. The new solution $v_{i}$ is created from $F_{i}$ utilizing a differential expression:

$$
s_{i, d}=F_{i, d}+r^{\prime} \times\left(F_{i, d}-F_{k, d}\right)
$$

where $d$ is randomly selected from $\{1, \ldots, D\}, k$ is randomly selected from $\{1, \ldots, \mathrm{SN}\}$ such that $k \neq i$, and $r^{\prime}$ is a uniform random number in the range $[-1,1]$. Once $s_{i}$ is obtained, it will be evaluated and compared to. If the fitness of $s_{i}$ is better than that of $x_{i}$ (i.e., the nectar amount of the new food source is higher than the old one), the bee will forget the old solution and memorize the new one. Otherwise, she will keep working on $x_{i}$.

Onlooker bee phase: In this stage, when every employed bee have completed their neighbourhood search, they share the nectar data of their food source with the onlookers, each of whom will then choose a food source in a probabilistic way. The probability $P b_{i}$ by which an onlooker bee picks food source $x_{i}$ is computed as takes after:

$$
P b_{i}=\frac{f_{i}}{\sum_{t=1}^{S N} f_{i}}
$$

where $f_{i}$ is the fitness value of $x_{i}$. Obviously, the onlooker bees tend to choose the food sources with higher nectar amount. Once the onlooker has selected a food source $x_{i}$, she will also conduct a local search on $x_{i}$ according to eqn. (6). As in the previous case, if the modified solution has a better fitness, the new solution will replace $x_{i}$. 
Scout bee phase: In the scout bee phase of ABC, if the quality of a solution cannot be improved after a predetermined number (limit) of trials, the food source is assumed to be abandoned, and the corresponding employed bee becomes a scout. The scout will then produce a food source randomly by using eqn. (5).

In this stage, if the nature of a solution can't be enhanced after a foreordained number of trials, the food source is thought to be surrendered, and the relating employed bee turns into a scout. The scout will then create a food source haphazardly by utilizing eqn. (5).

\section{RESULTS AND DISCUSSION}

The proposed method for the optimal scheduling of D$\mathrm{T}-\mathrm{O}$ in E-O-L reverse logistic based on ABC algorithm is implemented in the working platform of MATLAB 2014a, with the system configuration; Intel Core i5 processor, 8GB RAM and windows 8.1 operating system.

In this paper we used the information utilized as a part of the previous paper [28]. For this situation illustration we are considering $100 \mathrm{E}-\mathrm{O}-\mathrm{L}$ products and every products contains nine components. The components sort we are considering is PC and the components are numbered from 1 to 9 , the detail of components is given in table 1.

Table 1: Component detail per product

\begin{tabular}{|c|l|l|l|}
\hline Item & $\begin{array}{l}\text { Name of } \\
\text { component }\end{array}$ & Material type & Disassembly method \\
\hline 1 & Outer cover & Aluminium (A) & Destructive (D) \\
\hline 2 & Power supply & Copper (C) & Destructive (D) \\
\hline 3 & System fan & Plastic (P) & Destructive (D) \\
\hline 4 & RAM & Plastic (P) & Non-destructive (N) \\
\hline 5 & DVD Drive & Aluminium (A) & Non-destructive (N) \\
\hline 6 & Hard Disk slot & Plastic (P) & Destructive (D) \\
\hline 7 & CPU & Plastic (P) & Non-destructive (N) \\
\hline 8 & Heat sink & Aluminium (A) & Destructive (D) \\
\hline 9 & Hard disk & Aluminium (A) & Non-destructive (N) \\
\hline
\end{tabular}

The above given table 1 gives the bill of material (BOM), which incorporates the component detail alongside the kind of disassembly. All in all an E-O-L product may not contain all components; one or more parts may miss. Those missed segments are numbered as ' 0 '. The subtle element some of items are given in table 2 .

Table 2: Example E-O-L product details

\begin{tabular}{|l|l|l|}
\hline $\begin{array}{l}\text { Product } \\
\text { No }\end{array}$ & $\begin{array}{l}\text { Components } \\
\text { details }\end{array}$ & $\begin{array}{l}\text { Disassembly } \\
\text { Method }\end{array}$ \\
\hline 1 & 100000000 & D00000000 \\
\hline 2 & 100000002 & D0000000D \\
\hline 3 & 100000009 & D0000000N \\
\hline 4 & 100000089 & D000000DN \\
\hline 5 & 100000089 & D000000DN \\
\hline 6 & 100000789 & D00000NDN \\
\hline 7 & 100000789 & D00000NDN \\
\hline 8 & 100006789 & D0000DNDN \\
\hline 9 & 100056789 & D000NDNDN \\
\hline$\cdot$ & $\cdot$ & $\cdot$ \\
$\cdot$. & $\cdot$ & $\cdot$ \\
\hline & $\cdot$ & D00NND00N \\
\hline
\end{tabular}

The goal of the previous work was to make 20 new products from the accessible 100 E-O-L products. In perfect case we can acquire the greatest number of E-O$\mathrm{L}$ parts is 900 for 100 products. However, in down to earth case it is impractical, on account of the missing of products. From the information we utilized as a part of this paper the most extreme no of accessible components is 463 including both destructive and nondestructive. In this the greatest accessible nondestructive parts are 200 and destructive parts are 263. The complete non-destructive parts can be specifically utilized for the reuse with less measure of misfortune. A portion of the destructive component in the wake of remanufacturing or reusing it can be utilized for the reuse.

To make 20 new products we require 180 parts i.e. 20 number of every component sort is needed. So as to fulfil our necessity we have to take most extreme of 55 E-O-L items. Keeping in mind the end goal to choose the most suitable mix, to decrease the aggregate cost the AGA was utilized. The execution of the proposed methodology is contrasted and the current procedures like evolutionary programming (EP) and genetic algorithm (GA). From the correlation, the aggregate no of take back items by our proposed AGA procedure is 47, which are 6 numbers not exactly GA and 8 numbers not exactly EP. The aggregate dismantling cost by AGA methodology is $30 \mathrm{\$}$, which is 5 and 8 dollars not as much as that of GA and EP separately. The aggregate acquisition cost by AGA methodology is $25 \$$ which is one dollar not exactly both GA and EP. The aggregate expense for the complete opposite logistic by proposed AGA strategy is just 525\$ yet for GA and EP is 591 and 614 respectively.

In this paper we concentrated to reduce the disassembly time of the E-O-L products, so that an optimal scheduling framework based on $\mathrm{ABC}$ algorithm is proposed. Here we 47 products as the input product, for the disassembly, which are the take back E-O-L personal computers. Each product has 9 components, total available machines is 9 among 4 for disassembling the destructive component and 5 for non-destructive components. The average time taken by the various machines is given in the table 3 .

Table 3: Average time taken by the various machines

\begin{tabular}{|l|c|c|c|}
\hline $\begin{array}{l}\text { Non-destructive } \\
\text { Machine }\end{array}$ & $\begin{array}{c}\text { Time } \\
(\mathrm{Sec})\end{array}$ & $\begin{array}{c}\text { Destructive } \\
\text { Machine }\end{array}$ & $\begin{array}{c}\text { Time } \\
(\mathrm{Sec})\end{array}$ \\
\hline NM_1 & 33 & DM_1 & 11 \\
\hline NM_2 & 36 & DM_2 & 9 \\
\hline NM_3 & 35 & DM_3 & 13 \\
\hline NM_4 & 40 & DM_4 & 14 \\
\hline NM_5 & 32 & ----------- & ----- \\
\hline
\end{tabular}

The table 3 shows that the disassembly machine required more time for disassembling non-destructive machine than the destructive machine. Since nondestructive disassembly have to avoid damage of parts. The maximum average time required for the disassembly of the non-destructive component is 40seconds and minimum required time is 33 seconds for the given products. On the other hand for the disassembly of the destructive component machine 
required maximum of 14 seconds and minimum of 9 seconds. In order to validate the effectiveness of the proposed system the proposed system is compared with the evolutionary programming (EP) and Genetic algorithm (GA) in terms of disassembly. The disassembly time comparison is given in table 4 .

Table 4: Comparison on Disassembly time for the 47 products

\begin{tabular}{|c|c|c|c|}
\hline \multirow{2}{*}{ No of E-O-L Products } & \multicolumn{3}{|c|}{ Disassembly time (sec) } \\
\cline { 2 - 4 } & Proposed & GA & EP \\
\hline 47 & 223 & 247 & 280 \\
\hline
\end{tabular}

Table 5: Comparison on Total Cost for the 47 products

\begin{tabular}{|c|c|c|c|c|}
\hline \multirow{2}{*}{$\begin{array}{c}\text { No of E-O-L } \\
\text { Products }\end{array}$} & \multicolumn{4}{|c|}{ Total Cost (\$) } \\
\cline { 2 - 5 } & Proposed & AGA & GA & EP \\
\hline 47 & 498 & 525 & 591 & 614 \\
\hline
\end{tabular}

The disassembly time of the various technique for the D-T-O of 47 products obtained from the previous work is given in table 4 . The total time required for the disassembly of 47 products by the proposed optima scheduling algorithm is 223 seconds and by using the other methods like GA and EP is 247 and 280. It is clearly shows that the proposed scheduling framework can be a better option for the disassembly of E-O-L products in short time. In table 5 the total cost required for the D-T-O of 47 products is given. The total cost required for the disassembly of 47 products is 614,591 , 525 and 498 by using EP, GA, AGA and proposed. The table 4 and 5 shows that the consumption of time and cost for the disassembly of 47 products is better and low by using the proposed $\mathrm{ABC}$ based scheduling technique. In order to show the scheduling performance of the proposed framework, it is compared with the other scheduling algorithm by varying the number of E-O-L products and is given in table 6 .

Table 6: Comparison of scheduling algorithms in terms of Disassembly time

\begin{tabular}{|c|c|c|c|}
\hline \multirow{2}{*}{ No of E-O-L Products } & \multicolumn{3}{|c|}{ Disassembly time (sec) } \\
\cline { 2 - 4 } & Proposed & GA & EP \\
\hline 30 & 196 & 215 & 249 \\
\hline 40 & 202 & 221 & 266 \\
\hline 50 & 237 & 261 & 298 \\
\hline 70 & 256 & 289 & 320 \\
\hline 100 & 310 & 345 & 382 \\
\hline
\end{tabular}

Table 7: Comparison of scheduling algorithm in terms of Total Cost

\begin{tabular}{|c|c|c|c|c|}
\hline \multirow{2}{*}{ No of E-O-L Products } & \multicolumn{4}{|c|}{ Total Cost (\$) } \\
\cline { 2 - 5 } & Proposed & AGA & GA & EP \\
\hline 30 & 448 & 475 & 516 & 563 \\
\hline 40 & 487 & 502 & 578 & 597 \\
\hline 50 & 505 & 533 & 602 & 620 \\
\hline 70 & 536 & 558 & 645 & 656 \\
\hline 100 & 585 & 591 & 689 & 702 \\
\hline
\end{tabular}

The table 6 gives the comparison of scheduling algorithm by varying the number of products. The time required for the disassembly of the $30,40,50,70$ and 100 products is $196,202,237,256$, and 310 respectively by proposed method, 215, 221, 261, 289, and 345 respectively by GA and 249, 266, 298, 320, and 382 respectively by EP algorithm. In table7 the various scheduling algorithm in terms of total cost is compared the comparative analysis clearly shows that the total cost required by proposed algorithm is lower than that of the other previous and existing algorithms. The graphical representation of the scheduling algorithm comparison in terms of both disassembly time and total cost is given in fig 2 to 8 .

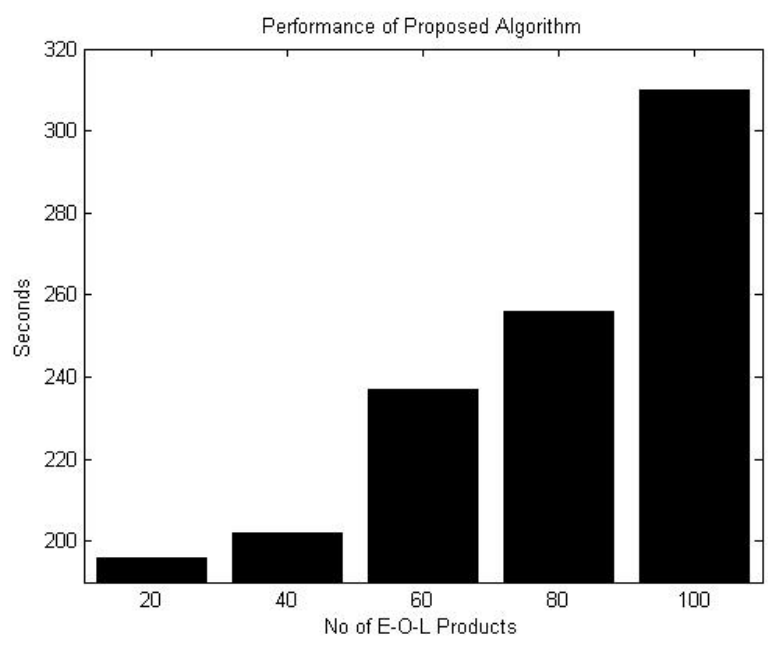

Figure 2: comparison of proposed scheduling in terms of disassembly time

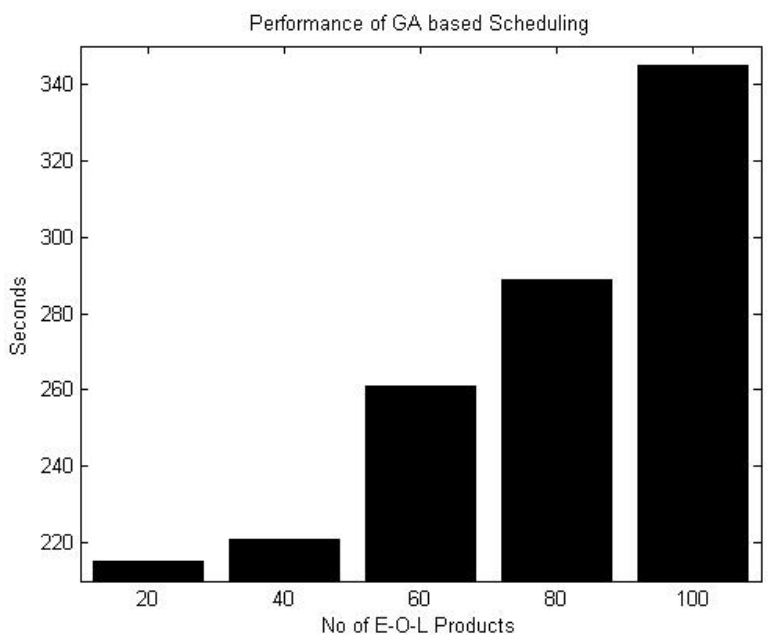

Figure 3: comparison of GA based scheduling in terms of disassembly time

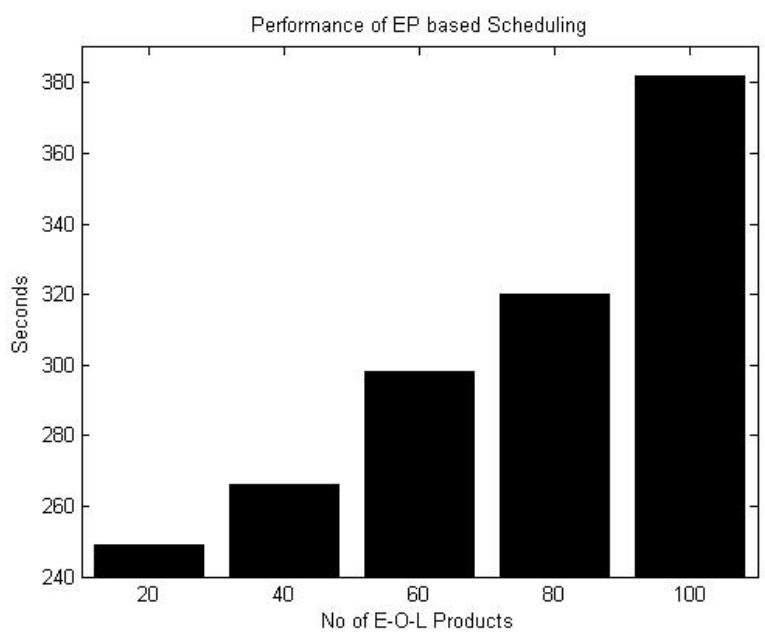

Figure 4: comparison of EP based scheduling in terms of disassembly time 
The fig 2 to fig 4 the disassembly time comparison of various techniques at different no. of E-O-L products is given.

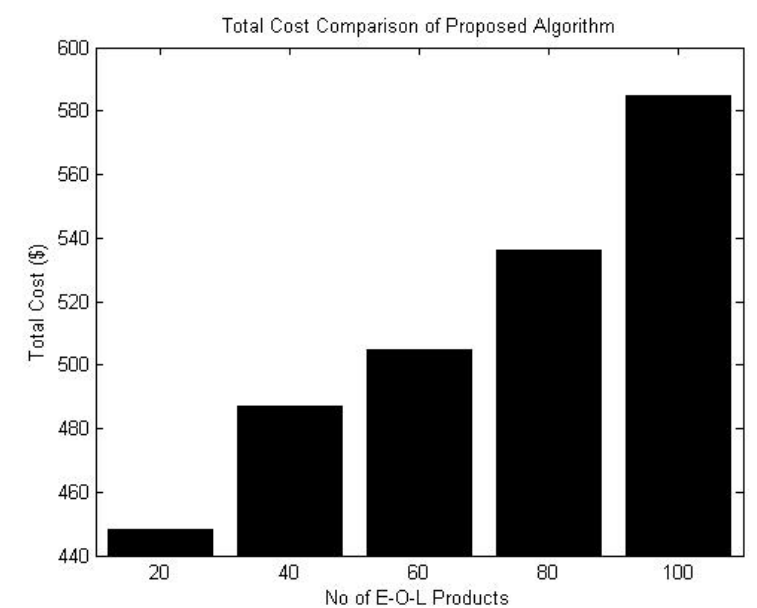

Figure 5: comparison of total cost at variable no. of E-O-L products by proposed

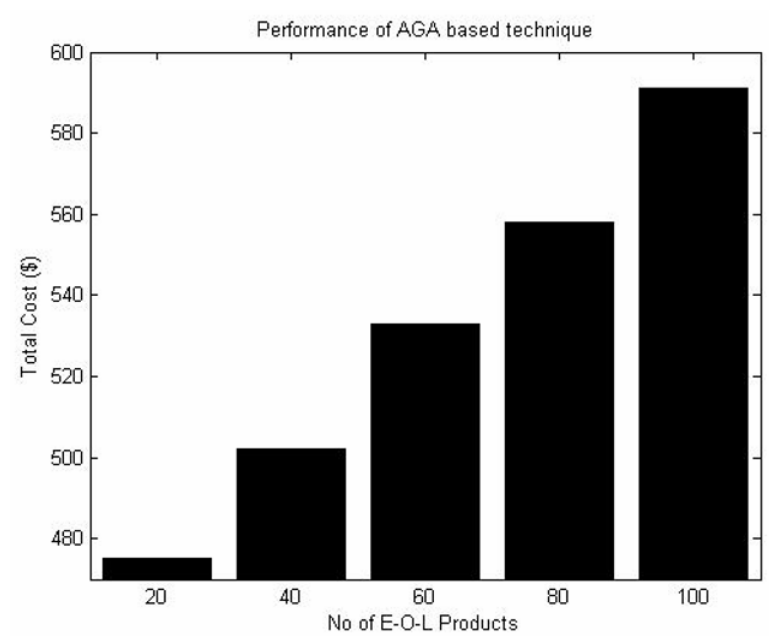

Figure 6: comparison of total cost at variable no. of E-O-L products by AGA

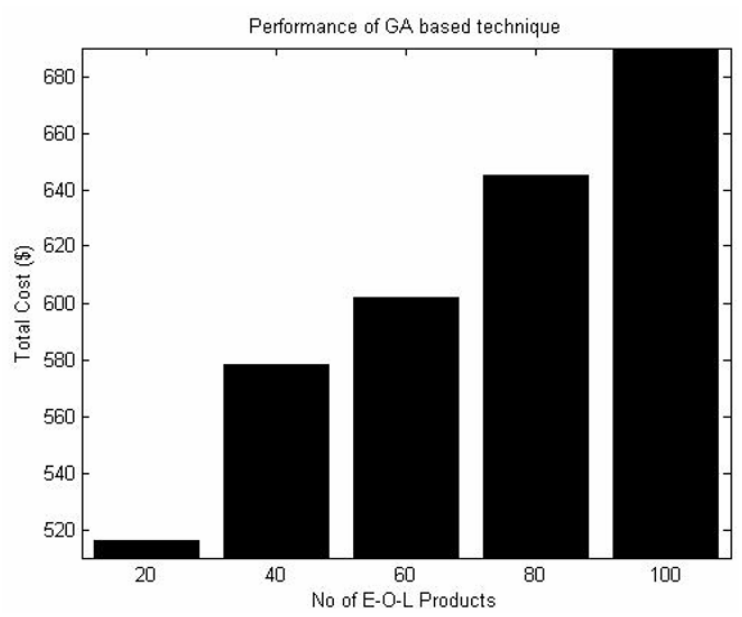

Figure 7: comparison of total cost at variable no. of E-O-L products by $\mathrm{GA}$

The performance comparison graphs given in fig 5 to 8 clearly shows the effectiveness of the proposed framework for the disassembly scheduling of E-O-L product in the reverse logistic operation. The effectiveness of optimization algorithm is shown by the convergence it is given in the fig 9 .

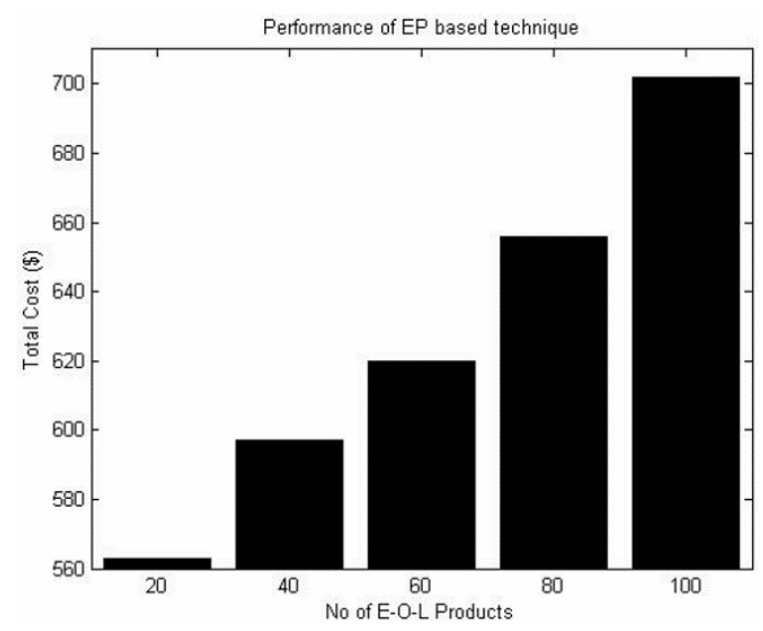

Figure 8: comparison of total cost at variable no. of E-O-L products by EP

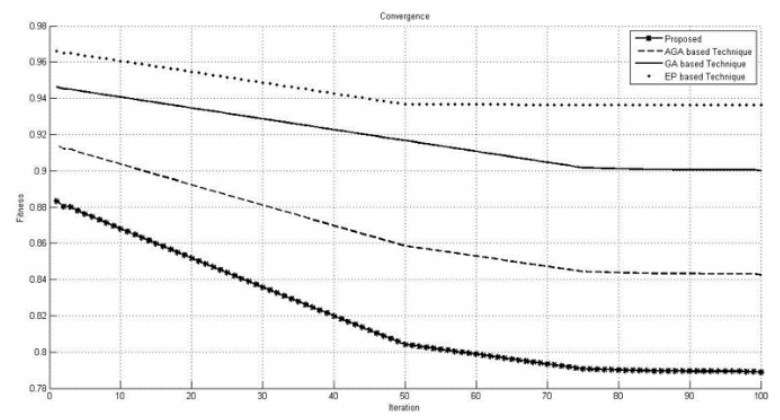

Figure 9: Convergence comparison

The convergence chart given in the fig 9 shows that the proposed optimization algorithm for the scheduling is converged well comparing to the other methods like GA based scheduling and EP based scheduling. The experimental results and performance analysis discussed so far, proves that the proposed framework for the disassembly scheduling of E-O-L product in reverse logistic (RL) can become a suitable technique to enhance the speed of RL process, so that the maximum profit can achieved.

\section{CONCLUSION}

The disassembly scheduling for the E-O-L product disassembly using ABC algorithm is proposed in this paper to reduce the RL operation time. The multi period D-T-O is essential for the manufacturer to meet the challenges in the technological words with new gadgets. The proposed system proposed a novel ABC based scheduling of D-T-O process, so that the time required for RL operation can reduced.

In reverse logistic of E-O-L product the cost can minimized by proper selection of number of take back products, which was done in our previous work [28], and in this paper the proper scheduling of the product is achieved for D-T-O process. Hence the disassembly can done properly with less effective, and short time. The proposed method is implemented in the working platform of Matlab, and performance is compared with the existing scheduling algorithms like GA and EP. The performance analysis proved that the proposed system has better performance than the existing methods, in terms of disassembly time. Thus we can suggest that the 
proposed framework is one of the best options for the implementation in the manufacturing industries for D-T$\mathrm{O}$ process.

\section{REFERENCES}

[1] Ram Ganeshan. and Terry P. Harrison.: An introduction to supply chain management, Department of Management Science and Information Systems, Penn State University, pp. 27, 1995.

[2] Ronald S. Tibben-Lembke. and Dale S. Rogers.: Difference between forward and reverse logistics in a retail environment, An International Journal of Supply Chain Management, Vol. 7, No. 5, pp. 271282, 2002.

[3] Xiangru, M.: Study of evaluation and selection in third party reverse logistics provider, In Proceedings of the international seminar on business and information management, pp. 518 521, 2008.

[4] Rogers, D.S. and Tibben-Lembke, R.S.: An examination of reverse logistics practices, Journal of Business Logistics, Vol. 22, No. 2, 129-148, 2011.

[5] Ciliberti, F., Pontrandolfo, P. and Scozzi, B.: Logistics social responsibility: Standard adoption and practices in Italian companies, International Journal of Production Economics, Vol. 113, No. 1, pp. 88-106, 2008.

[6] Zhu, Q., Sarkis, J. and Lai, K.: Green supply chain management implications for closing the loop, Transportation Research Part E: Logistics and Transportation Review, Vol. 44, No. 1, pp. 1-18, 2008.

[7] Dat, L.Q., Linh, D.T.T., Chou, S.Y. and Yu, V.F.: Optimizing reverse logistics cost for recycling endof-life electrical and electronic products, Expert Systems with Applications, Vol. 39, No. 7, pp. 6380-6387, 2012.

[8] Ilgin, M.A. and Gupta, S.M.: Environmentally conscious manufacturing and product recovery: A review of the state of the art, Journal of Environmental Management, Vol. 91, No. 3, pp. 563-591, 2010.

[9] Mutha, A. and Pokharel S.: Strategic network design for reverse logistics and remanufacturing using new and old product modules, Computers \& Industrial Engineering, Vol. 56, No. 1, pp. 334 346, 2009.

[10] Gungor A. and Gupta, S.M.: Issues in Environmentally Conscious Manufacturing and Product Recovery: A Survey, Computers and Industrial Engineering, Vol. 36, No. 4, pp. 811-853, 1999.

[11] Prahinski, C. and Kocabasoglu, C.: Empirical research opportunities in reverse supply chains, Omega, Vol. 34, No. 6, pp. 519-532, 2006.

[12]D. S.Rogers and R. S. Tibben-Lembke, "An examination of reverse logistics practices", Journal of Business Logistics, Vol. 22, No. 2, pp. 129-148, 2011.

[13] Grenchus, E., Keene, R. and Nobs, C.: Demanufacturing of Information Technology Equipment, In Proceedings of the 1997 IEEE International Symposium on Electronics and the Environment, San Francisco, California, pp. 157160, 1997.

[14] Guide, Jr., Srivastava, R. and Spencer, M. S.: An Evaluation of Capacity Planning Techniques in a Remanufacturing Environment, International Journal of Production Research, Vol. 35, No. 1, pp. 67-82, 1997.

[15] Bloemhof-Ruwaard, J.M., Beek van, P., Hordijk, L. and Van Wassenhove, L. N.: Interactions Between Operational Research and Environmental Management, European Journal of Operational Research, Vol. 85, pp. 229-243, 1995.

[16] Moyer, L. and Gupta, S.M. Environmental Concerns and Recycling / Disassembly Efforts in the Electronics Industry, Journal of Electronics Manufacturing, Vol. 7, No. 1, pp. 1-22, 1997.

[17] Gupta, S.M., Taleb, K.N.: Scheduling Disassembly, International Journal of Production Research, Vol. 32, pp. 1857-1886, 1994.

[18]Lee, D.H., Xirouchakis, P., A Two-Stage Heuristic for Disassembly Scheduling with Assembly Product Structure, Journal of the Operational Research Society, Vol. 55, pp. 287-297, 2004.

[19] Kim, H.J., Lee, D.H., Xirouchakis, P., Zust, R.: Disassembly Scheduling with Multiple Product Types, Annals of the CIRP, Vol. 52, pp. 403-406, 2003.

[20]Taleb, K.N. and Gupta S.M.: Disassembly of Multiple Product Structures, Computers and Industrial Engineering, Vol. 32, pp. 949-961, 1997.

[21] Taleb, K.N., Gupta, S.M. Brennan L.: Disassembly of Complex Product Structures with Parts and Materials Commonality, Production Planning and Control, Vol. 8, pp. 255-269, 1997.

[22]Lee, D.H., Kim, H.J., Choi, G. and Xirouchakis, P.: Disassembly Scheduling: Integer Programming Models, Proceedings of the Institution of Mechanical Engineers: Journal of Engineering Manufacture - Part B, Vol. 218, pp. 1357-1372, 2004.

[23]Lee, D.H., Xirouchakis, P. and Zust, R.: Disassembly Scheduling with Capacity Constraints, Annals of the CIRP, Vol. 51, pp. 387-390, 2002.

[24] Luu Quoc Dat., Doan Thi Truc Linh., Shuo-Yan Chou. and Vincent F. Yu.: Optimizing reverse logistic costs for recycling end-of-life electrical and electronic products, Expert Systems with Applications, Vol. 39, pp. 6380-6387, 2012.

[25] Chunguang Bai. and Joseph Sarkis,: Flexibility in reverse logistics: a framework and evaluation approach, Journal of Cleaner Production, Vol. 47, pp. 306-318, 2013. 
[26] Mahdi Mahmoudzadeh., Saeed Mansour. and Behrouz Karimi.: To develop a third-party reverse logistics network for end-of-life vehicles in Iran, Resources, Conservation and Recycling, Vol. 78, pp. 1-14, 2013.

[27] Sónia R. Cardoso., Ana Paula, F.D., BarbosaPóvoa. and Susana Relvas.: Design and planning of supply chains with integration of reverse logistics activities under demand uncertainty, European Journal of Operational Research, Vol. 226, pp. 436-451, 2013.

[28] Harold Krikke., Dianne Hofenkc. and Yacan Wang.: Revealing an invisible giant: A comprehensive survey into return practices within original (closed-loop) supply chains, Resources, Conservation and Recycling, Vol. 73, pp. 239-250, 2013.

[29] Sathish, T. and Jayaprakash, J.: Meta-Heuristic Approach to Solve Multi Period Disassembly-toorder Problem of End-of-life Products using Adaptive Genetic Algorithm, International Joural of Mechanical \& mechatronics Engineering IJMMEIJENS, Vol. 15, No. 3, pp. 59-67, 2015.

\footnotetext{
ПЕРИОДИЧНО РАСТАВЉАҢЕ ПО НАРУЏБИНИ ПРОИЗВОДА КОЈИМА ЈЕ ИСТЕКАО РОК НА ОСНОВУ ПЛАНИРАҢА МАКСИМИЗАЦИЈЕ ПРОФИТА КОД ОПЕРАЦИЈЕ ПОВРАТНЕ ЛОГИСТИКЕ
}

\section{Т. Сатиш, Џ. Џајапракаш, П. В. Сентхил, Р. Сараванан}

У новије време производња електронских производа је све већег обима, што доводи до стварања велике количине електронског отпада. Ово је последица очекивања да се иновације стварају у кратком временском периоду. Такве околности наводе произвођаче да креирају нове производе за кратко време, па се они морају или одлагати или растављати. Произвођачи су намеравали да прераде, тј. поново произведу, производе којима је истекао рок употребе да би задовољили потребу за новом компонентом.

У том смислу смо у нашем претходном раду приказали методологију избора оптималног броја производа које треба узети назад, тако да се укупни трошкови потребни за повратну логистику могу смањити. У овом раду приказана је нова методологија повратне логистике примењене на производе којима је истекао рок, са аспекта алгоритма оптималног планирања. У претходном раду смо утврдили оптималан број производа које требе раставити по наруџбини, а у овом раду приказујемо поступак планирања машина које треба да обаве растављање, тако да се могу смањити укупни трошкови и време потребно за операцију повратне логистике. Предложили смо структуру алгоритма вештачке колоније пчела. Такав оквир усмерава побољшане перформансе преко постојећег алгоритма планирања. 